THE MAGIC OF CONCEPTS 
This page intentionally left blank 


\section{THE MAGIC OF CONCEPTS}

History and the Economic in Twentieth-Century China

REBECCA E. KARL

DUKE UNIVERSITY PRESS

Durham and London

2017 
(C) 2017 Duke University Press

All rights reserved

Printed in the United States of America

on acid-free paper $\infty$

Typeset in Minion Pro and Gill Sans

by Westchester Book Group

Library of Congress Cataloging-in-Publication Data

Names: Karl, Rebecca E., author.

Title: The magic of concepts : history and the economic in twentieth-century China / Rebecca E. Karl.

Description: Durham : Duke University Press, 2017. |

Includes bibliographical references and index.

Identifiers: LCCN 2016035966 (print) |

LCCN 2016037766 (ebook)

ISBN 9780822363101 (hardcover : alk. paper)

ISBN 9780822363217 (pbk. : alk. paper)

ISBN 9780822373322 (e-book)

Subjects: LCSH: China-Economic policy-1912-1949. |

China-Economic policy-1976-200o. |

China-History-2oth century-Historiography. |

China-Politics and government-History-2oth century.

Classification: LCC HC427 .K27 2017 (print) |

LCC HC427 (ebook) | DDC 330.0951/0904-dc23

LC record available at https://lccn.loc.gov/2016035966

Cover photo: Motion blur in the Shanghai Sightseeing

Tunnel. Sean Pavone / Alamy Stock Photo. 
FOR DAVID.

WITH LOVE AND IN MEMORY.

YOU WILL ALWAYS BE MY PERSONAL CONCEPT OF MAGIC. 
This page intentionally left blank 